\title{
Shifting Perspectives in Assessing Socio-Environmental Vulnerability
}

\author{
Jonathan W. Long $1, *$ (1) and E. Ashley Steel ${ }^{2,3}$ \\ 1 USDA Forest Service, PSW Research Station, Davis, CA 95618, USA \\ 2 USDA Forest Service, PNW Research Station, Seattle, WA 98103, USA \\ 3 Present: Forestry Department, Food and Agricultural Organization (FAO) of the United Nations, Viale delle \\ Terme di Caracalla, 00153 Rome, Italy; ashley.steel@fao.org \\ * Correspondence: jonathan.w.long@usda.gov; Tel.: +01-530-759-1744
}

Received: 17 February 2020; Accepted: 24 March 2020; Published: 26 March 2020

\begin{abstract}
Governments and institutions across the globe are conducting vulnerability assessments and developing adaptation plans to confront rapidly changing climatic conditions. Interrelated priorities, including the conservation of biodiversity, ecological restoration, sustainable development, and social justice often underlie these efforts. We collaborated with colleagues in an effort to help guide vulnerability assessment and adaptation (VAA) generally in Southeast Asia and specifically in the watershed of the Sirindhorn International Environmental Park (SIEP) in Phetchaburi Province, Thailand. Reflecting upon our experiences and a review of recent VAA literature, we examine a series of seven questions that help to frame the socio-ecological context for VAAs. We then propose a three-dimensional framework for understanding common orientations of VAAs and how they appear to be shifting and broadening over time, particularly in the USA. For example, key leaders in the SIEP project emphasized social development and community-based approaches over more ecology-centric approaches; this orientation was consistent with other examples from SE Asia. In contrast, many efforts for US national forests have evaluated vulnerability based on projected shifts in vegetation and have promoted adaptation options based upon ecological restoration. Illustrating a third, highly integrated approach, many VAAs prepared by indigenous tribes in the USA have emphasized restoring historical ecological conditions within a broader context of promoting cultural traditions, social justice, and adaptive capacity. We conclude with lessons learned and suggestions for advancing integrated approaches.
\end{abstract}

Keywords: vulnerability and adaptation assessment; climate change; ecological restoration; watershed management; sustainable development; community-based assessment; indigenous peoples

\section{Introduction}

Entities around the globe are increasingly engaged in assessing vulnerability and developing plans to adapt to climate change. International efforts were catalyzed at the 21st Conference of the Parties to the United Nations Framework Convention on Climate Change (COP21) by the adoption of an agreement for all participating countries to develop climate change adaptation plans [1]. Such planning efforts are now connected to broader sustainability initiatives, such as the UN Decade on Ecosystem Restoration (2021-2030), for which the United Nations General Assembly has set a goal of massively scaling up the restoration of degraded and destroyed ecosystems to address climate change and promote sustainable ecosystems. A first step in identifying appropriate actions and policies in the face of climate change is often to conduct a vulnerability and adaptation assessment (VAA). In fact, this is frequently a required step in accessing climate preparedness funds [2]. Vulnerability assessments identify future risks induced by climate change, identify key vulnerable resources, and provide a sound 
basis for designing adaptation strategies [3]. A recent trend among vulnerability assessments has been to expand considerations to include social, non-climatic determinants of vulnerability, such as adaptive capacity, and to shift from simply estimating expected damages to identifying opportunities to reduce damages [4]. Another thrust has been to recognize the concerns of local communities, particularly underserved and highly vulnerable communities, including indigenous peoples [5]. Both COP21 and a related international agreement, the Convention on Biological Diversity, have explicitly called for the consideration and integration of indigenous communities into their strategies [6]. Alongside these trends there has been a shift from qualitative descriptions of vulnerability to more quantified evaluations of risk, including the probability of occurrence of hazards, potential exposure to hazards, and the severity of potential impacts [7].

\subsection{Background}

We were invited to share the perspectives and ideas used by the US Forest Service (USFS) in developing VAAs with a team of government agencies, universities, and non-governmental organizations (NGOs) in central Thailand that was initiating one of the first watershed-scale VAA efforts in Southeast Asia. Over the course of three in-person visits and extensive remote collaboration, we both contributed to the completion of the project and learned about collaborative, large-scale VAA initiatives. In this paper, we consider the key issues and lessons that emerged from that experience in the context of scientific literature describing the principles and approaches of successful VAA efforts. We begin by describing the framework of the particular project in Thailand and then review guidance from the USFS as well as literature regarding VAAs and ecological restoration. We then present seven questions that emerged as points of tension during the project, and we reframe those issues in light of recent literature and published examples of VAAs from national forests and tribes in the USA. Based upon that review and our engagement in the cross-cultural project as a case study, we suggest ways to shift toward more integrated VAAs.

\subsection{SIEP Project Case Study: Watershed-Scale Climate Vulnerability Assessment and Adaptation Planning in Thailand}

The Watershed-Based Adaptation to Climate Change project was a regional collaborative initiative financed by the National Research Council of Thailand (NRCT), Royal Thai Government, and US Agency for International Development (USAID) with technical support from the USFS. The initiative aimed to create a model for watershed-scale planning through a VAA for Sirindhorn International Environment Park (SIEP) in Cha-am District, Phetchaburi Province, Thailand (hereafter, the SIEP project) (Figure 1). The park has been developed to educate visitors about energy, natural resources, and the environment in the coastal region of Thailand, with a special emphasis on the conservation of mangrove habitats. It is located in one of the driest parts of Thailand, a region important for agriculture, including lemons and pineapple, and tourism, including golf courses and hotels. The SIEP project included the participation of research faculty from two Thai universities, park staff, representatives of several ministries, and leadership by the Sustainable Development Foundation (SDF), a well-established non-governmental organization in the region. 


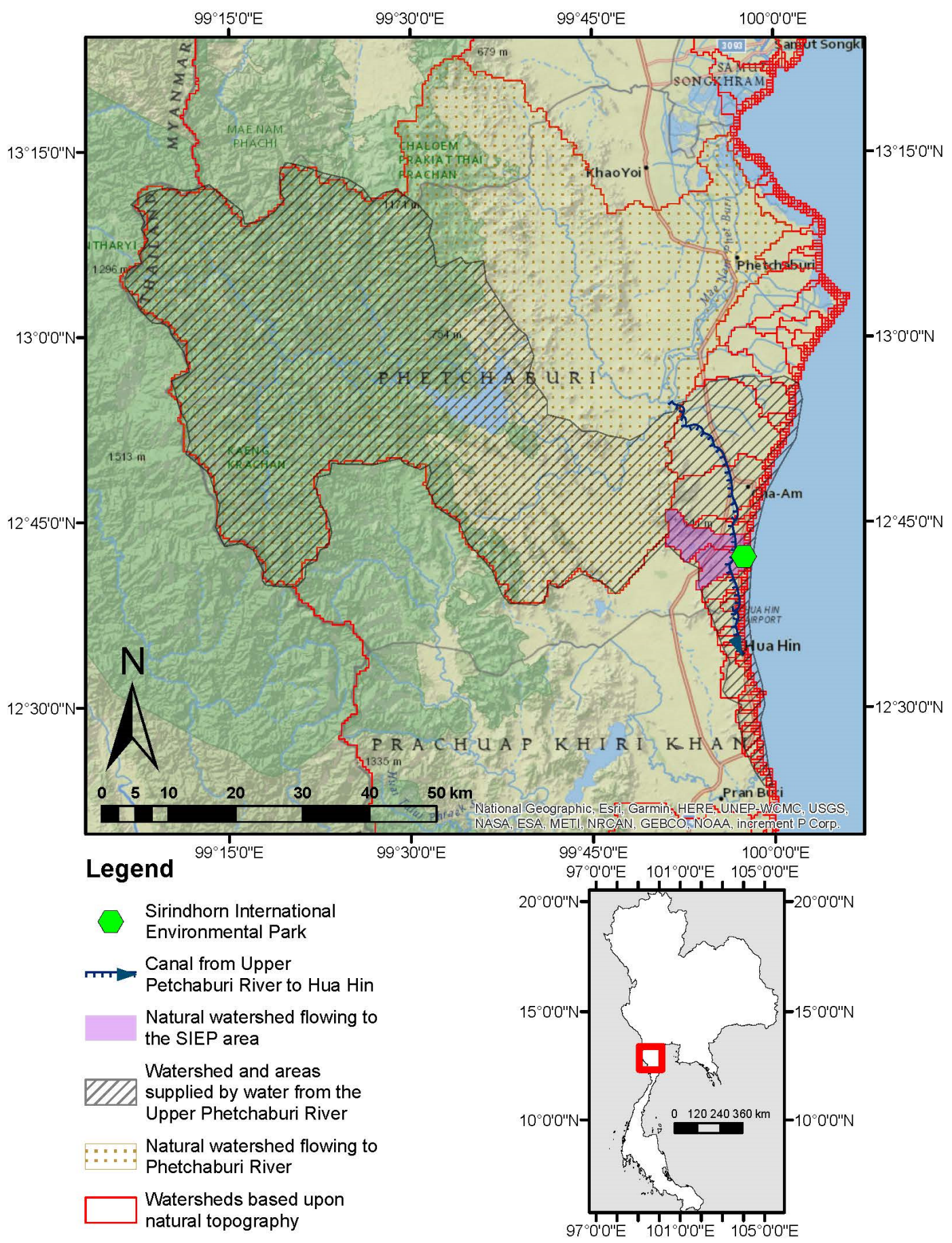

Figure 1. The natural watershed of the Sirindhorn International Environmental Park (SIEP) (light purple) is much smaller than the watershed of the Upper Phetchaburi River (brown stippling) that supplies water to coastal areas, including the area around the park (gray hatching).

The project included climate downscaling work across the entire Phetchaburi River Basin (Figure 1) as well as on-the-ground data collection in communities selected by the SDF to represent the main economic sectors in the watershed. In the upper watershed, the SDF focused on a Karen community that was experiencing conflict with the government regarding land rights and agricultural activities, as are other indigenous people in mountainous forested areas [8]. In the central watershed, the SDF identified four villages that each relied on a particular cash crop and two communities struggling with urban expansion and water supply management. In the lower watershed, the SDF focused on three communities suffering from floods and droughts as well as a community where many livelihoods 
depended on salt farming. Their methodology explicitly considered both climate and non-climate factors that contribute to vulnerability [9].

\section{Review of Vulnerability Literature}

\subsection{Guidance for VAAs in the US}

USFS reports and related journal articles from the past dozen years reveal how ecological and socio-economic issues have been addressed in VAA guidance over time. In 2008, the USFS released a strategic framework for responding to climate change [10], which was followed by a more detailed "roadmap" [11]. Additionally in 2008, the US government published a "preliminary review of adaptation options for climate-sensitive ecosystems and resources"; the authors of the chapter on national forests authored a related journal article the following year [12]. Over the next few years, the USFS issued guidance reports for VAAs including a guidebook for developing adaptation options with case study examples in 2010 [3], a guide to adaptation tools and resources references in 2012 [13], and a framework with pilot assessments for watershed vulnerability in 2013 [14].

The early guidance and examples of VAAs on national forests focused heavily on the ecological dimensions of vulnerability. Although they also mentioned ecosystem services, they often considered socio-economic factors in terms of being added stressors or constraints. For example, Spies et al. [15] noted how "social license", policies, and laws might constitute barriers to adaptation. Vulnerability was commonly evaluated in terms of biophysical values, including wildlife, forests, fisheries, and infrastructure. For example, three pilot examples of watershed vulnerability assessments from national forests in the Pacific Northwest evaluated only the impacts to aquatic species listed as rare or threatened by government agencies as well as to infrastructure including roads, campgrounds, and water diversions [14]. Most national forests in the USA are situated within inland mountain regions; consequently, most examples of detailed vulnerability analyses from the USFS are from such areas [3]. These rural areas have relatively low human population densities and few permanently populated areas. Early VAAs may have largely ignored the social vulnerability of local communities in order to focus on the quantification of biophysical risks. Many of these early VAAs stand in contrast to examples from Southeast (SE) Asia that focused on densely populated urban areas [16].

USFS guidance for VAAs has recently shifted toward a greater focus on socio-economic dimensions of vulnerability through the lenses of ecosystem services and household adaptive capacity. In 2013, Fischer et al. [17] published an article calling for greater attention to social vulnerability in assessments for national forests. In 2016, the USFS updated the adaptation guidance published four years earlier to include urban forests [18]. Most recently, the USFS issued guidance for integrating socio-economic concerns into vulnerability frameworks [19] and protocols for evaluating socio-economic vulnerability [20].

The impact of climate change on indigenous communities has also been an emerging concern in VAA literature pertaining to US national forests. Many of the USFS guidance documents do not specifically draw attention to indigenous peoples, although one of the recent reports [20] mentions some values that are particularly important to such communities, including traditional foods and medicinal herbs. To address this gap, the USFS recently published a framework for understanding climate impacts on indigenous peoples that highlights impacts on tribal social systems [21]. That guidance notes that classifications such as "natural," "cultural", and "economic" reflect colonial systems of thinking that impose false divisions between fundamentally interconnected systems, as highlighted in other tribally directed research [22]. A group led by a team of indigenous people in the North Central USA recently published an adaptation menu that responded to earlier USFS guidance by featuring words, processes, and values that they thought would be more productive and respectful for work involving indigenous communities [23]. American Indian tribes have been broadening the scope of VAAs in the USA-a recent review [24] found that VAAs written by or for tribes in the Pacific Northwest USA emphasized how climate change would impact their distinctive cultural values. 
Nearly half of the plans examined in that review specifically discussed impacts to public health, tribal economies, and cultural well-being, including traditional knowledge and cultural practices.

\subsection{An Evolving Foundational Concept: Ecological Restoration}

Ecological restoration has emerged as a common framework for addressing multiple natural resource management challenges, including the promotion of local livelihoods, sustainable development, conservation of biodiversity, mitigation of climate change, and adaptation to disturbances including climate change [25]. Proponents of restoration suggest that these efforts can be broadly relevant when customized to particular landscape and social contexts [26]. For example, the mission statement for the UN Decade of Landscape Restoration suggests that achievement of sustainable development goals depends on addressing ecological degradation. The concept of ecological restoration has had a wide and deep influence on conservation efforts in the United States and within the USFS in particular. The USFS roadmap invoked a future-looking form of ecological restoration as a central pillar to its efforts: "the agency is responding to climate change through adaptive restoration-by restoring the functions and processes characteristic of healthy ecosystems, whether or not those systems are within the historical range of variation" [11]. Additionally, restoration has been incorporated in the new forest planning rule to guide the revision of land management plans across the USA.

The ecological restoration framework is not rigidly prescriptive, but instead emphasizes principles, indicators, and best practices. Ecological restoration plans in the Pacific Northwest of the USA have often set targets based upon conditions prior to colonization by Europeans that are characterized as the "historical" or "natural range of variation" [27]. These restoration efforts may focus on evaluating and restoring native species diversity as well as natural processes that reset succession, such as fires and floods. While restoration has focused on removing artificial constraints on those natural disturbances, adaptation efforts have often focused on building resistance and resilience to uncharacteristically severe disturbances [12].

Linkages between ecological restoration and adaptation to climate change are common in USFS VAA literature. For example, Peterson et al. [3] described one climate change adaptation strategy of "forestalling change" as "intensifying management to return a site to a prior condition of that ecosystem in the face of climate change", which mirrors ecological restoration. Through interviews for his dissertation research, Timberlake [28] found that national forestland managers were largely focused on the goal of ecological restoration in pursuing climate change adaptation.

Ecological restoration appears less common, however, in VAA examples from SE Asia. For instance, a recently published guide to VAAs in the Greater Mekong subregion [2] did not include the terms "restore" or "restoration". Similarly, in a comparative study of socio-ecological system resilience in the United States and SE Asia, MacQuarrie [29] included several references to salmon and river restoration in his case study of the Columbia River Basin (US) but only one to forest restoration in Cambodia. An example for high mountain areas in Asia produced by the World Wildlife Fund did propose ecosystem restoration as one solution to reduce climate vulnerability [30]. Because there are so many diverse examples of VAAs in both regions, it is less important to demonstrate consistent differences between them than it is to consider how particular orientations can influence project outcomes.

\section{Findings from the Review and Case Study}

\subsection{Important Framing Questions Considered in the SIEP Project}

Through our efforts to bring ideas and frameworks from the USFS to the SIEP project, we identified several framing questions for consideration in structuring the scope and scale of any large-scale or watershed-scale VAA. 


\subsubsection{What Is the Appropriate Management Unit?}

Approaches applied to US national forests and in Southeast Asia have both emphasized the importance of using watersheds as analysis and management units. Guidance for conducting climate change vulnerability assessments in the USFS references a framework for assessing the watershed vulnerability at relevant scales, typically with hydrologic units that are 4000 to 16,000 ha [14]. This approach has been widely used in USFS lands that typically constitute headwater forests. The USFS has examined the national vulnerability of water supplies to climate change [31]. As a simplifying assumption, it did not consider the adaptive capacity of the water supply systems to respond to changes in precipitation; yet, extensive reservoir and irrigation systems do allow for storage and redistribution of water, representing adaptive capacity to manage changes in precipitation.

The SIEP project applied a "ridge to reef" approach that considered watershed areas in a similar size range. During our project, however, we confronted a challenge in simply identifying the boundaries of the watershed for the park because trans-basin diversions (Figure 2) had transformed the natural "ecological" watershed (based upon topography and historical conditions) into a much larger "water supply" watershed (Figure 1). Specifically, the park is located within the Bangtranoi watershed $\left(64 \mathrm{~km}^{2}\right)$ with hydrologic connections to the neighboring Huaisai watershed $\left(20 \mathrm{~km}^{2}\right)$ [32]. Although the Thai Royal Forest Department manages the forested mountain areas that have been recognized as priority water quality management zones, concerns over water supply were pronounced and not only related to headwater conditions. Both the agriculture and tourism sectors depend on water supplies from outside of the study-area basin. Water distribution plans were designed to balance human needs while leaving some minimal in-stream flows. In the project, the emphasis on consumptive use drew attention away from the forested highlands of the interior and toward the agricultural and urbanized areas along the coast.

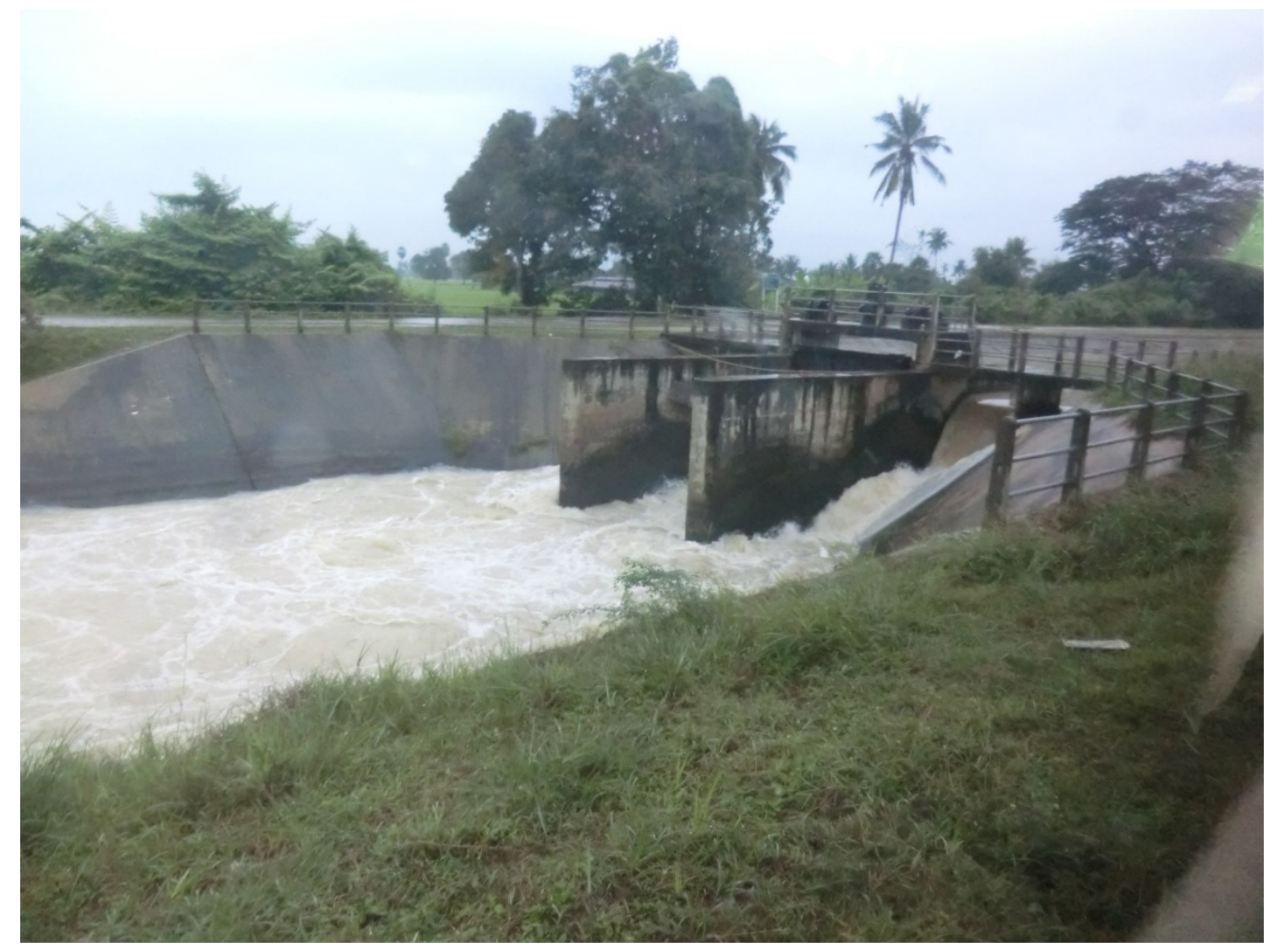

Figure 2. Water conveyance structure delivering water from storage reservoirs outside the SIEP watershed to downstream agriculture, cities, and tourism-related development. Photo by Jonathan Long. 


\subsubsection{Is Downscaled Climate Data Necessary?}

Because projections from global climate models are generally coarse, regional and local projects may rely on downscaling [33] to understand how climate change is likely to affect particular watersheds and landscapes [34]. Decisionmakers may prize this customized scientific information for gauging the susceptibility of highly built environments to natural disturbance. For example, downscaled climate data can play a role in predicting future flood flows and the vulnerability of bridges and other infrastructure. However, downscaled climate data may give the impression of being more precise and accurate that it truly is. It is not necessarily useful [35] and, in particular, it may be a distraction when managing wildland systems, which have evolved under a wide range of natural variation and which, therefore, may be more tolerant of climatic fluctuations than constructed systems. Additionally, thresholds for natural systems are less likely to be known, so precise estimates of environmental change may not be of high value.

Organizers of the SIEP project had a strong desire to create and utilize downscaled climate change data. Previously published research by Shrestha [36] included climate projections on an approximately $22 \times 22 \mathrm{~km}^{2}$ scale, to evaluate conditions across nine hydrological response units in Thailand; SIEP is included in the Eastern Gulf unit. Their findings suggest an increase in water availability during both the wet and dry seasons; however, they noted that the models did not perform as well in the coastal regions as in other regions. To address such concerns, the SIEP project commissioned downscaled climate projections at the $1 \mathrm{~km}$ scale.

While developing such finely downscaled climate projections can increase the reported precision of predictions and bolster confidence among decision makers, the fine scale of the predictions may also inflate expectations that the projections are accurate. Because there can be considerable uncertainty associated with localized forecasts, USFS guidance on VAAs [14] urges staff on individual national forests to proceed with VAAs even without finely downscaled climate projections. Often existing information, such as historical information on climate change and observations in extreme years, can be used for framing climate change in terms that are clearly understood and appreciated [37]. In fact, the ranges and directions of projected change may be more important than specific estimates for future temperature and runoff [14].

\subsubsection{Is Ecological Restoration or Socio-Economic Development the Priority?}

Many VAAs undertaken in Asia emphasize socio-economic development and immediate livelihood needs [35]. This focus contrasts with ecologically oriented VAA examples from the USFS. Even nature-oriented institutions such as the World Wildlife Fund have generated vulnerability assessment reports that explicitly evaluate impacts on ecosystem services and community livelihoods [30]. In the SIEP project, scientists and managers did highlight historical degradation including the loss of forest cover, soil erosion and reduced infiltration, sedimentation, the loss of mangrove habitats, and losses of important wildlife species including axis deer (Axis porcinus). Local watershed managers and park exhibits described conditions prior to the death of King Rama VI in 1926 as being a reference, comparable to the way the USFS often describes reference conditions prior to "Euro-American settlement". However, during the SIEP project, we observed that managers were focused on increasing forest and ground cover more than on restoring historical composition and structure. For example, activities described under forest restoration included planting vetiver grass (Chrysopogon zizanioides, native to India) and terracing landscapes to reduce soil erosion (Figure 3). Such actions, while bearing similarities to early soil restoration efforts on US national forests [38], are not aimed at restoring pre-existing conditions but rather at moving the ecosystem forward toward greater productivity. Managers may have favored such reparative actions as being more practical than attempting to recreate historical conditions. Some VAAs have explicitly blended restoration and economic development goals. One such VAA from the Philippines [39] concluded that an "ideal program" for reducing the vulnerability of farmers should combine reforestation to improve denuded watershed conditions with infrastructure enhancements to help farmers cope with floods and water shortages. 


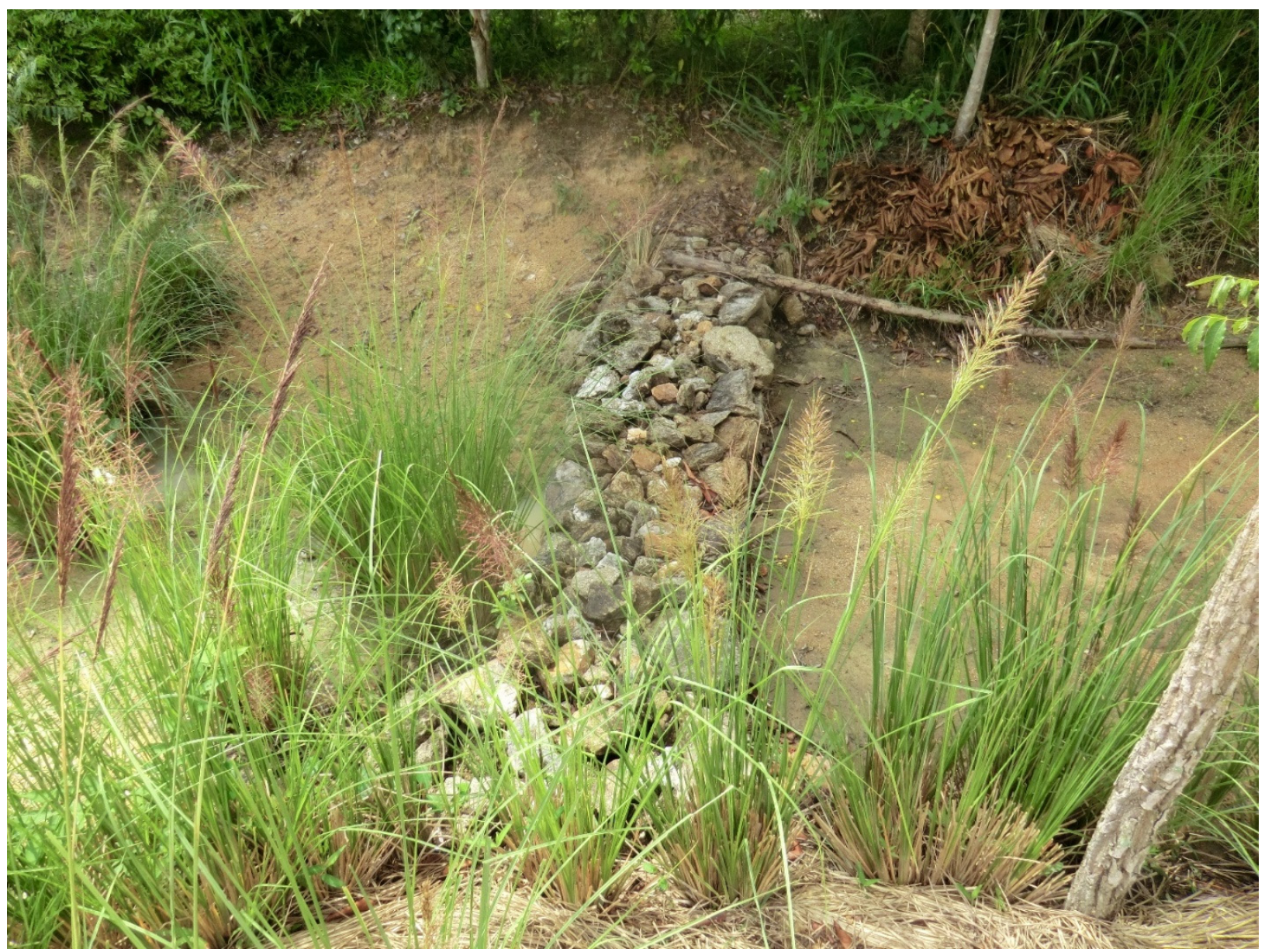

Figure 3. Erosion control measures including rock check dams and plantings of vetiver grass. Photo by Jonathan Long.

\subsubsection{Are Roads an Ecological Liability or a Resource for Reducing Social Vulnerability?}

Roads represent a significant boundary element in social and ecological systems, illustrating the need for an integrated perspective that weighs a variety of ecological and social values. In many US examples, VAAs have suggested closing and even obliterating roads because of concerns over their impacts on watershed condition [40]. These are most often in watersheds where limiting human impact is a goal. On the other hand, tribes have emphasized the need for access via roads to maintain traditional practices [41]. In SE Asia, VAAs have also recognized the importance of roads as adaptive capacity [42], because road access is essential for getting goods to market and for receiving services during emergencies.

\subsubsection{What Are the Costs and Benefits of Dams and Diversions?}

The negative impacts of dams and diversions have been highlighted in VAAs in the USA, while the benefits of such hydrologic infrastructure for ameliorating the impacts of floods and droughts are recognized in watershed management plans for the Phetchaburi River in Thailand. Adaptation plans in the USA and Europe emphasize reducing the impacts of dams and diversions, leaving "room for the river" [43] and otherwise promoting the use of soft adaptable green bank stabilization measures rather than streambank armoring and channelization [44] (Figure 4). VAAs for the Mekong River, where millions of people depend on fishing for their livelihoods and diet, have similarly emphasized these ecological principles [2]. In comparing system resilience in the USA and SE Asia, MacQuarrie [29] concluded that the construction of large dams in the Pacific Northwest USA had reduced ecological resilience, but that those impacts were counterbalanced by increased social resilience that stemmed 
from a focus on ecological restoration as well as on the legal and political power of tribes, fishers (commercial and recreational), and other stakeholders. In contrast, he concluded that social systems in SE Asia were less socially resilient, but that they had not experienced as much loss in ecological resilience. However, ecosystems in SE Asia, like the Mekong, are also experiencing declines in large migratory fish species (comparable to salmon and sturgeon in the Mekong, are also experiencing declines in large migratory fish species (comparable to salmon and sturgeon in the Columbia Basin) due to the construction of large dams [45]. Trans-boundary institutions have developed in the region to reduce the ecological impacts of dams, representing another source of adaptive capacity [46].

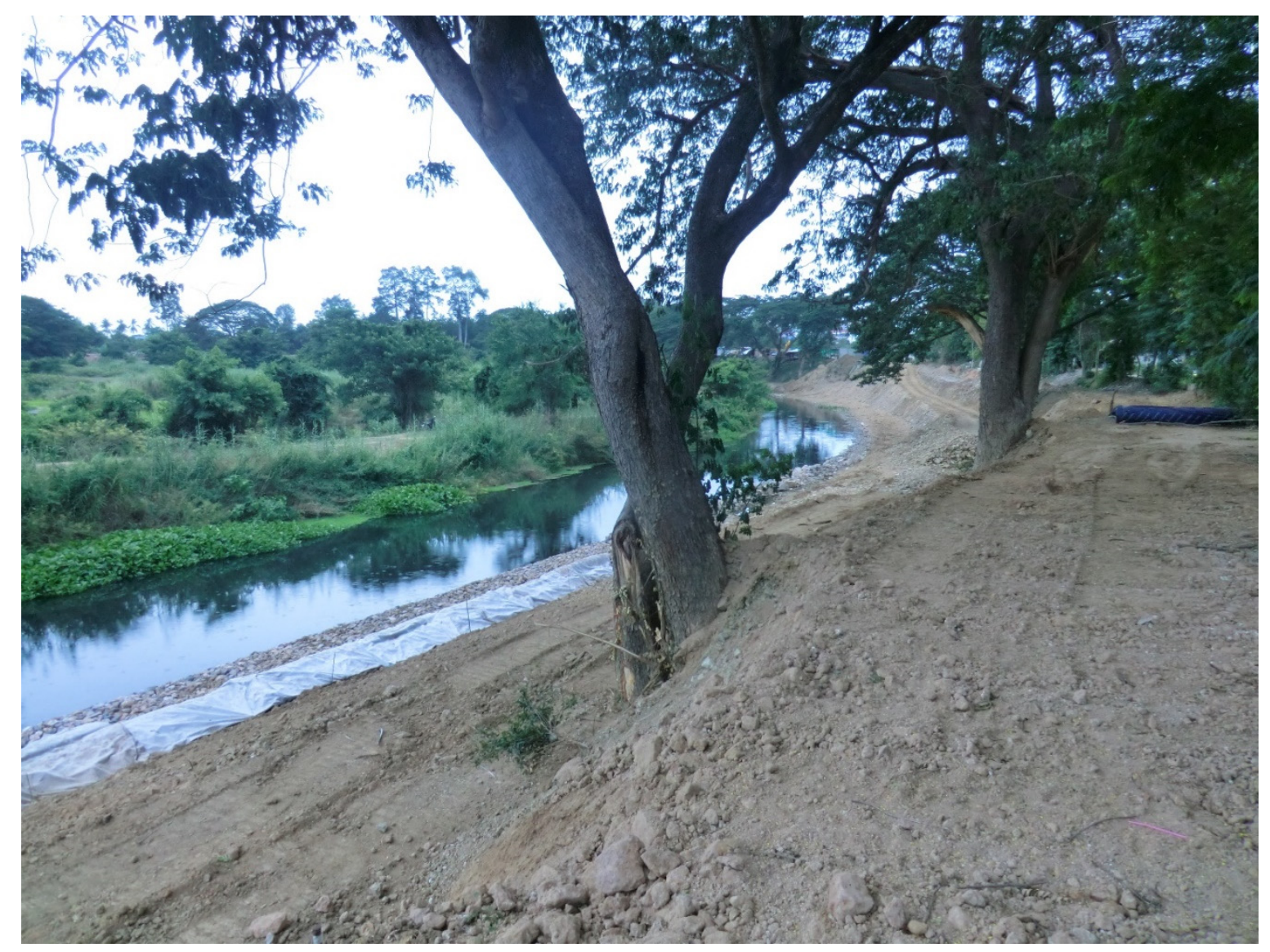

Figure 4. Channelization on a river system in the SIEP watershed. Photo by Jonathan Long.

\subsubsection{Is the Focus on Sustaining Forests or Sustaining Forest-Dependent People?}

In the SIEP case study, the use of forest lands by local communities, both for subsistence agriculture (Figure 5) and for the gathering of forest products, emerged as an important issue. Such issues also occur on federal lands in the United States, and they are a particularly significant issue for Native Americans [41,47]; however, neither have featured prominently in climate change vulnerability assessments. Both national parks and national forests in the United States have a long history of driving out and excluding indigenous peoples [48,49]. NGO staff leading the community-based assessment for the SIEP project described the adoption across SE Asia of what they considered to be a "Western model" of evicting local peoples from conservation lands such as national parks (see [50] for more on that history). Similarly, a VAA for the Philippines [39] expressed concern that adaptation strategies focusing on forest restoration and protection might not address the needs of communities, noting that forest protection rules could adversely affect farmers without official land tenure. 


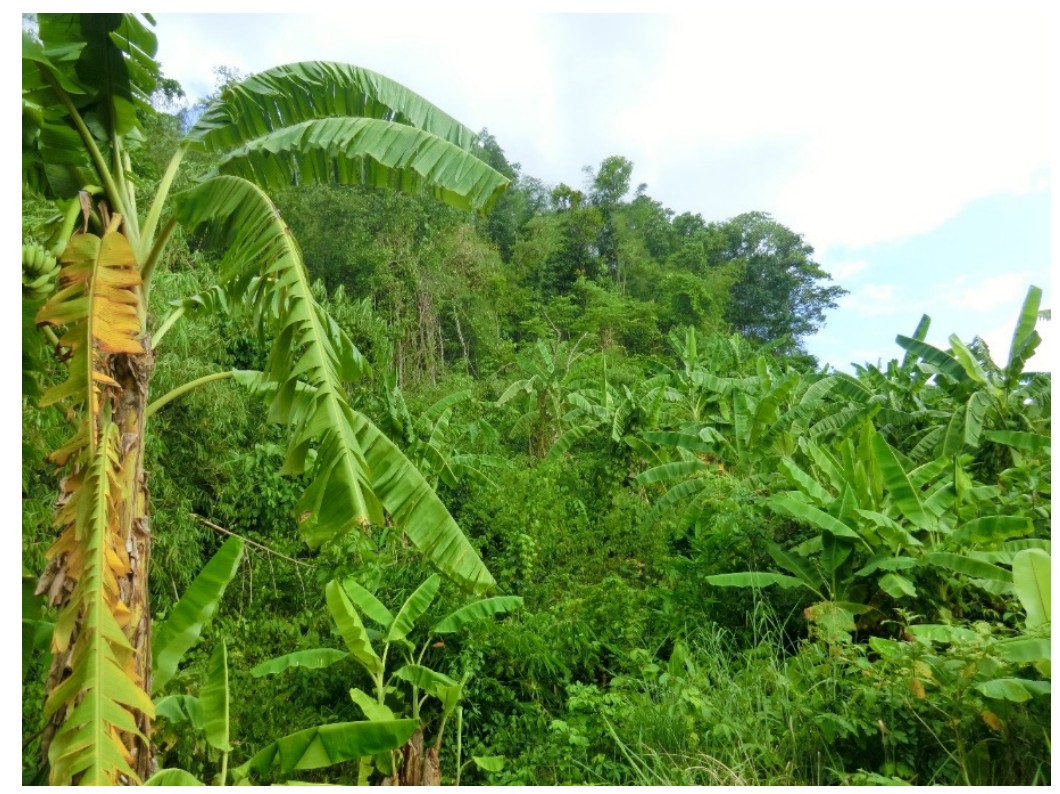

Figure 5. Crops planted within patches cleared from forests in the upper watershed by local communities. Photo by Jonathan Long.

\subsubsection{Is Fire to Be Restored or Excluded?}

Tensions in applying an ecological restoration framework are particularly evident in debates over whether human-caused burns should be part of a management regime to restore reference conditions. In tropical parts of the USA and affiliated islands, suppression of wildfires is a predominant concern and human-set fires are often regarded as unnatural and harmful [51]. A similar view appears to hold in many parts of SE Asia, although some researchers and community organizations maintain that rotational agriculture using fire to clear forest patches is a long-standing practice, going far back in human history. The dry dipterocarp forest found in the SIEP project area has likely had a long history of fire influence; however, the importance of fire in altering its succession to evergreen forest remains a topic of some uncertainty [52]. In the national park at the headwaters of the SIEP project area, the impacts of Karen people using fire to clear forests were a high concern; yet, community members asserted that they were continuing a long-standing tradition of swidden agriculture. In the Western USA, management of fire regimes has long been a dominant concern in watershed management and the adaptation to climate change, but the focus has recently shifted toward restoring more frequent and lower intensity fire that mimics cultural burning by indigenous peoples [41]. Some tribes in the USA have also sought to restore traditional agroforestry practices, such as cultural burning, to national forests encompassing ancestral lands [41] as part of a management plan to promote resilience to future climate change $[53,54]$.

\subsection{General Themes in VAAs Represented by Three Axes}

By considering the key questions above that emerged in our case study as well as the trends in the reports and journal articles discussed above, we identified three major axes shaping the orientation of VAAs (Figure 6). First is the extent of focus on the ecological versus socio-economic dimensions of systems. Second is the level of reliance on technical "experts" versus broader community participation as sources of information. Third is the time frame for evaluating departure from desired conditions. The three axes in the figure are in theory independent, but as a practical matter, assessments have tended to cluster between top-down and ecologically focused versus bottom-up and socially focused. 


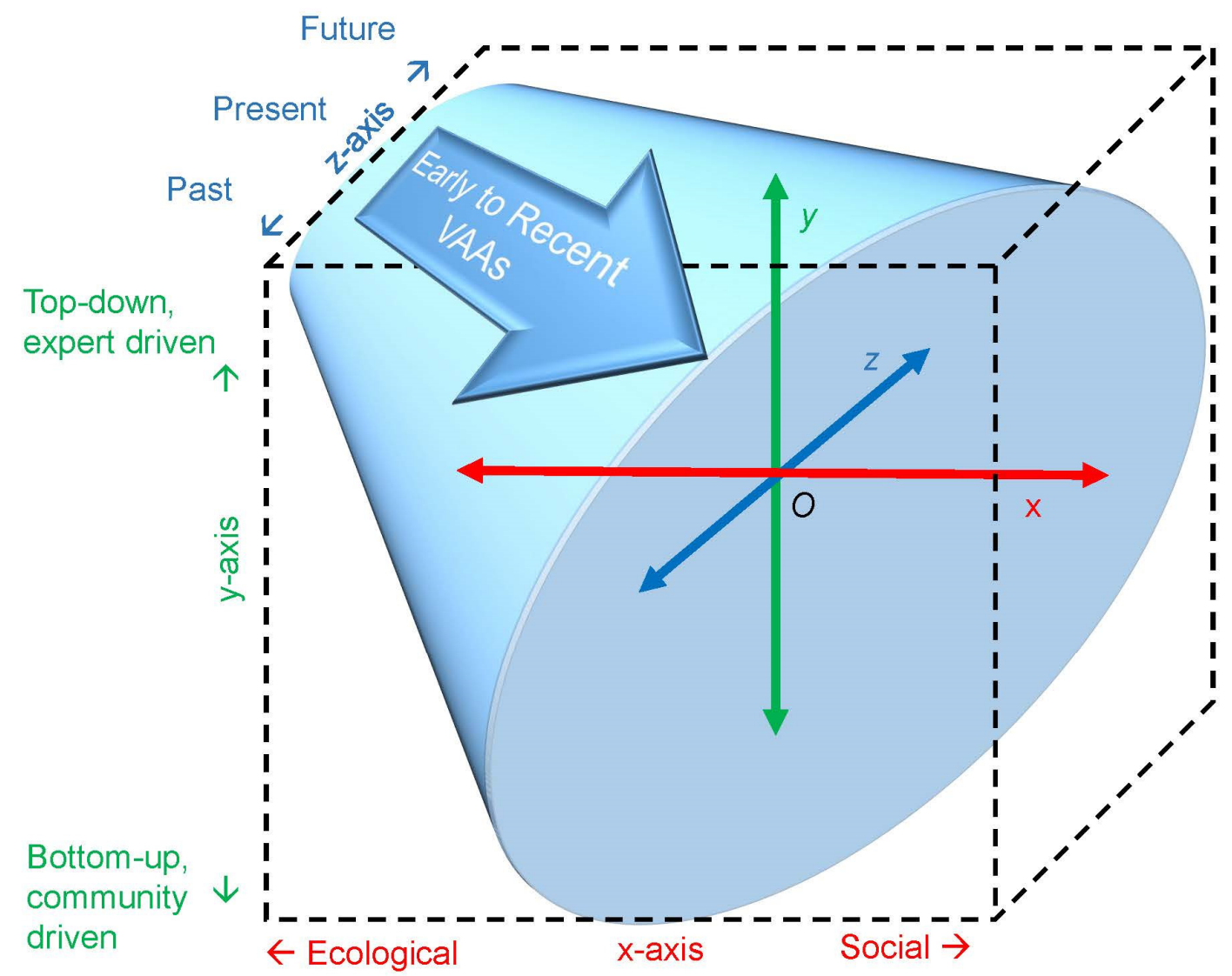

Figure 6. The scope of vulnerability and adaptation assessments. The x-axis represents the social-ecological orientation. The y-axis represents bottom-up versus top-down processes, and the $\mathrm{z}$-axis represents the temporal perspective including past, present, and future reference points.

\subsubsection{Social-Ecological Considerations}

The first axis describes the relative emphasis on social versus ecological issues and outcomes. Many of the differences between VAA along this axis relate to broader tensions between social development and conservation.

Early reports and associated articles written on VAA issues for national forests in the USA recognized both ecological and socio-economic systems; however, they focused heavily on the ecological aspects, such as how the distribution of dominant species or the associated plant communities may shift. Social concerns have been incorporated into such frameworks by focusing on species that are harvested for commercial gain or subsistence, or which are "charismatic" [55]. Social dimensions in early VAA efforts also included the consideration of ecosystem services [10], such as impacts to water supply and recreation [14] as well as the consideration of how to bolster internal agency adaptive capacity and reduce external social and economic barriers to adaptation $[3,56]$.

The language used in many VAAs indicates their predominantly ecological orientation. For example, Timberlake and Schultz [57] noted that "In (US) Forest Service documents, the agency frequently uses resilience in the sense of ecological resilience; it sometimes describes social-ecological resilience but to date has rarely worked this type of resilience into planning and management activities." In another article, they noted that considerations of ecosystem services were often limited to qualitative descriptions [58]. An ecological focus is often reflected in terms such as "landscape" to characterize areas. In contrast, the perspective of tribes or other indigenous communities is often important in viewing such areas instead as "homelands" that they depend upon to sustain their livelihoods and identities. 
In Southeast Asia, many regional VAAs have emphasized poverty reduction and the associated socio-economic concerns. For example, the USAID Mekong Adaptation and Resilience to Climate Change (ARCC) project [2] considered impacts to livestock, fisheries, agriculture, natural systems, and health and rural infrastructure. It focused its assessment on six principal crops and applied downscaled global climate projections to evaluate impacts to livelihoods. Impacts to "natural systems" were considered through the lenses of non-timber forest products and wild relatives of key crops. This perspective is consistent with the idea that many forested landscapes in the Mekong Basin are used for agroforestry. Other regional assessments have also integrated social and ecological evaluations [42].

\subsubsection{Information Sources and Process}

The second dimension (the y-axis in Figure 6) focuses on the sources of information used to prepare the assessment. A "bottom-up" approach focuses on local knowledge. It may rely upon local observations of climate trends and qualitative information, often obtained through interviews with community members or participatory processes. A "top-down" approach depends more heavily on detailed scientific data, published studies, downscaled climate projections, and expert opinion. For example, experts often review literature and suggest indicators that they think are useful for measuring vulnerability [59].

Bottom-up approaches have become a priority for many communities that have been frustrated when government agencies develop plans first and seek buy-in from local communities second. Communities often prefer to have priorities and plans emerge from local concerns and to gain agency buy-in as a second step. Green et al. [60] stressed that the latter, "bottom-up", approaches may better develop practical activities to reduce vulnerability; they cautioned that decision makers may become stuck in an information gathering and research phase if they prioritize having quantitative justification for particular policy options. Eriksen et al. [61] also emphasized the need to pursue adaptation actions that promote both social justice and environmental integrity by integrating local knowledge into adaptation responses and by recognizing the importance of non-climate stressors [15]. Non-profit organizations leading VAA efforts in other parts of Asia have emphasized the need to address the non-climate dimensions of vulnerability through community engagement at local scales [35].

In the USA, individual national forests have typically completed VAAs on their own, although one plan was developed jointly between the Olympic National Forest and Olympic National Park [40]. Early VAAs by the USFS placed considerable emphasis on the technical expertise of internal agency staff, as well as external scientists from universities and non-profit conservation organizations. These efforts may not be strictly characterized as "top-down", because they were often built on information from stakeholder workshops with participation from universities, NGOs, local governments, and other interests. Yet, lists of participants suggest that staff and scientists with biophysical expertise often predominated. Timberlake [28] similarly noted that the USFS has emphasized a "coproduction" model involving scientists and managers. One of the planning guides suggested that broader community considerations could be addressed by previewing VAAs with stakeholders who may be affected [24]. The top-down approach may also be triggered by short planning horizons; plans are often created relatively rapidly, taking between eight months and one year to complete [14].

In contrast, VAAs in SE Asia frequently emphasize multi-agency approaches, which may take several years to complete. For example, the Mekong ARCC project worked over several years assessing conditions across many communities. The SIEP project involved multiple consultations with stakeholders mostly composed of local community members. The consultations were of various sizes and locations and took place over two years. Several recent examples of VAAs have highlighted more participatory processes that seek to integrate top-down and bottom-up approaches $[62,63]$.

\subsubsection{Temporal References}

The third axis describes the temporal orientation of the assessments, which typically compare conditions during two different time periods. For example, restoration plans commonly compare 
present conditions to those during a past reference period. Using a past reference period can help address the pervasive effects of colonization, which are a major concern of indigenous groups [64]. As Helen Fillmore, a tribal member and climate change researcher recently explained, "The degradation that they [our elders] couldn't fathom is already our current condition" [65]. To address these concerns, researchers have attempted to estimate historical changes in indicators that are socially and ecologically important, such as the availability of traditionally harvested wild foods [22].

Some researchers contend that historical conditions may no longer be appropriate or realistic in the face of changing climate [3]. In that vein, early USFS guidance suggested that VAAs be more forward-looking by considering simulations of future climate, vegetation, and species movements [3]. Indeed, early examples of VAAs in the USA often assessed ecological vulnerability based upon such modeled climate projections and judgments of their adaptive capacity by professional scientists. Many of these assessments implicitly set a present-day reference by comparing current conditions to future conditions that are projected using models of climate change.

Many socially oriented VAAs are oriented toward current conditions, rather than forecasts, to evaluate vulnerability. As a practical matter, trends in key social indicators are often challenging to predict. For example, fewer than half of health-oriented VAAs internationally have estimated the future health impacts of climate change; that limitation reflects a common lack of data and analysis regarding relationships between climate drivers and health outcomes on which to build predictive models [66]. Other socially oriented VAAs have focused on vulnerability to widely predicted climatic impacts, particularly for low-lying coastal regions, such as increases in temperature, increased risk of intense storms and flooding, and sea-level rise [67-69].

Some researchers contend that while modeling to predict future conditions is valuable, it is important to focus on present-day vulnerabilities informed by community input [35]. For example, O'Brien et al. [70] argued for an emphasis on human security and present difficulties in coping with external stressors, which they characterized as "context vulnerability". They contrasted that approach with the assessment of "outcome vulnerability" that may develop in the future. Williams et al. [71] further emphasized this point by distinguishing between impacts that have already been "realized" versus "potential" impacts that might occur. Some economists have suggested that focusing on current demand for services, rather than their potential supply, is important for aligning policy with sustainable development goals [72].

\subsection{Lessons Learned for Achieving Better Integrated VAAs}

Over the past dozen years, there has been a trend toward greater social-ecological integration of VAAs in the USA. Here we present lessons learned that may reinforce this shift toward more integrated perspectives in advancing the sustainability of coupled human-natural systems.

\subsubsection{Humans are Part of Most Natural Systems}

Frameworks in North America have broadened to consider the influence of humans in the evolution of natural ecosystems. For example, the use of fire by indigenous peoples, which has occurred for thousands of years in North America, is increasingly regarded as part of the natural disturbance regime under which many ecosystems in the Western United States have evolved [73,74]. Accordingly, particular ecological communities, including groves of large California black oaks (Quercus kelloggii) and Oregon white oaks (Quercus garryana), camas grounds (Camassia spp.), and rock-walled "clam gardens" are recognized as having been produced or shaped by indigenous practices and are now targets for ecological restoration $[41,75,76]$. A recent indigenous-led publication supplemented USFS guidance on VAAs by emphasizing more holistic perspectives in adaptation planning rather than worldviews and language that tend to separate humans from the natural world [23]. 


\subsubsection{The Ecological Restoration Framework Can Be Broadened to Include Social Considerations}

The longstanding ecological restoration framework remains a powerful and appealing tool for evaluating conditions and setting management directions; however, research has recommended greater focus on social indicators and consideration of local community perceptions when evaluating baselines for ecological restoration [77]. Furthermore, ecological restoration has the potential to contribute to injustices if strategies do not account for social impacts. Accordingly, many planners, even some within the restoration field, have encouraged greater attention to social objectives [78].Ecological restoration can be more closely allied with environmental justice and indigenous concerns than has been commonly recognized, as revealed in the ecocultural restoration movement being advanced by many tribes [79]. This movement emphasizes the important of access to traditional foods and medicines for community health, which aligns with calls for VAAs to evaluate the impacts of climate change on the public health and food security of vulnerable populations $[66,80]$.

3.3.3. Consideration of Social Adaptive Capacity, Including Governance Institutions, May Increase the Relevance of VAAs

Socially oriented VAAs consider how communities can adapt to the future climate given institutions, policies, property rights, and other constraints that humans are able to change [81]. Promoting adaptive social capacity may align with many ecological restoration goals, particularly for communities that have been impacted by declines in the productivity of ecosystems. However, that focus may also bring a wider range of possible targets under management consideration than would be considered under a purely ecological restoration perspective, which may become narrowly fixated on past ecological conditions. Governance institutions, which are an important component of adaptive capacity, are especially important for the management of harvested systems or resource allocations $[82,83]$. The ecological restoration framework in the USA can also be used to align shared ecological interests of non-governmental entities including watershed councils, prescribed fire councils, and other groups. An increasing responsiveness of institutions to the interests of indigenous communities, with support or pressure from federal law, has been important for promoting system resilience, especially in the Pacific Northwest of the USA [29]. Tribes in the USA have pursued institutional relationships that facilitate more cooperative management, such as comanagement agreements and the establishment of special demonstration areas [41,75]. These developments have propelled important ecological restoration efforts, such as the removal of large dams that have inhibited recovery of salmonids.

\subsubsection{Community Engagement in the Development of Indicators May Increase Their Effectiveness}

Evaluations of socio-ecological resilience may be greatly influenced by the selection of indicators. Because of that, MacQuarrie [29] noted that adaptive capacity could be increased by engaging local stakeholders in creating and studying a more complete inventory of indicators. During the SIEP project, we discussed a variety of climate indicators or "facets" that would translate climate change projections into locally meaningful terms, such as the duration of floods and length of rainy periods that impact specific crops. For example, the local community wanted to create an indicator describing the maximum number of consecutive days without rain in the growing season. This indicator contained information critical to anticipating climate effects on particular crops and to making decisions about what to plant in the future. While emphasizing values that are important to community stakeholders, these facets can be built on recommended principles of scientific reliability [59]. Work with tribes in the US has similarly emphasized biophysical metrics to quantify the usability and availability of key forest product species, including the abundance of mature hardwood trees that produce culturally important foods [84,85]. Assessments will be more likely to result in social change where indicators have been developed in collaboration with local communities [86]. 


\subsubsection{Integrated Science and Monitoring Contribute to Effective Management in the Long Term}

Monitoring efficient, ecologically important, and socially meaningful indicators can help ensure that adaptation efforts are effective in reducing vulnerability. However, the outcome of a particular adaptation approach may not be evident for years after it is put into practice, and long-term, retrospective evaluations of plan implementation are rare. Most countries have not completed a cycle of adaptive management by evaluating the sufficiency of baseline assessments and monitoring the success of adaptation efforts [66]. An openness to experimentation may be particularly important for advancing the adaptation science knowledge base, particularly when experiments are designed with consideration of governance institutions and with the engagement of local communities [87]. Support for conducting experiments may depend on alignment with social and cultural values. For example, attitudes that regard humans as part of nature, as held by many Native Americans, have been associated with public support for interventions to conserve Alaska yellow cedar under a warming climate, even within protected forest areas [88].

\subsubsection{Integration of Top-Down and Bottom-Up Approaches Is Necessary to Solve Complex Problems}

Many recent examples of VAAs aim to integrate perspectives from professional scientists and local communities. The value of such integration is that broader knowledge is brought to bear on complex problems. The USAID Mekong ARCC framework [2] pursued this goal by integrating a "community-based vulnerability assessment" with a "science-based vulnerability assessment," to build a community-driven adaptation plan, which was subjected to expert review. A recent VAA in Thailand illustrated such an approach, as researchers compared community views that precipitation was becoming more variable with projections of increased precipitation overall [62]. Another effort in the Mekong Basin found that participatory approaches helped to bridge divides over adaptation priorities between investments in infrastructure versus changes in land-use policies [63]. In their review of USFS VAAs, Timberlake and Schultz [58] suggested that a greater focus on social-ecological linkages and key ecosystem services could be achieved by involving stakeholders in participatory processes that integrate qualitative case studies and top-down quantitative assessments. While bottom-up approaches are important for ensuring community engagement, top-down support can help to design and implement more rigorous experimental efforts that can be replicated and upscaled [87]. As part of such a mixed-methods integrative approach, local qualitative inquiries can help stakeholders prioritize quantitative investigations on broader scales [89].

\section{Conclusions}

Tension between top-down approaches, which are steeped in the quantitative analysis of biophysical impacts of climate change, and bottom-up approaches, which emphasize participatory and qualitative examination of social capacity and development opportunities, will always be present in VAAs. However, the past decade of VAA applications in the USA has shifted from predominantly "ecologically focused" VAAs toward more holistic ones. This trend reflects a broader recognition that planners and managers need to move beyond problematic distinctions between "ecological" and "social" dimensions when promoting sustainable systems. Our summary risks overgeneralizing differences between VAA approaches applied in US national forest contexts and ones that have been commonly applied in SE Asia. The seeming divergence likely reflects multiple factors, including the different priorities of federal land management agencies such as the USFS, compared to non-governmental socio-economic development institutions that have had prominent roles in VAAs in SE Asia. Moreover, VAAs in both regions are increasingly assessing joint ecological and social impacts and identifying opportunities to increase adaptive capacity through institutional change. Assessing vulnerability and developing effective adaptation plans will require a skillful combination of perspectives, including relatively standardized, quantitative measures of future risk along with more locally customized assessments of community vulnerability and adaptive capacity. 
Author Contributions: Conceptualization, writing, and editing: J.W.L. and E.A.S.; literature review and figures: J.W.L. All authors have read and agreed to the published version of the manuscript.

Funding: This research received funding support from the USDA Forest Service Pacific Northwest Research Station and Pacific Southwest Research Station based upon a partnership with the US Agency for International Development.

Acknowledgments: We thank Monthip Sriratana Tabucanon, Ravadee Prasertcharoensuk, Alex Smajgl, Jonathan Shott, Jerasorn Santisirisomboon, and Robert Dobias for sharing insights regarding vulnerability assessments in Southeast Asia. We also thank Kathy Lynn and Haley Case-Scott for sharing findings from their compilation and review of vulnerability assessment and adaptation plans developed by tribes in the USA. We thank Geoffrey Blate for his expertise and his contributions to illuminating insights from the SIEP project as well as for providing feedback on a draft of this manuscript.

Conflicts of Interest: The authors declare no conflict of interest.

\section{References}

1. United Nations Framework Convention on Climate Change. Adoption of the Paris Agreement FCCC/CP/2015/L.9/Rev.1; United Nations Framework Convention on Climate Change: Paris, France, 2015.

2. Smajgl, A.; Salamanca, A.; Steel, A.; Blate, G.; Long, J.; Hartman, P.; Manuamom, O.; Sawhney, P.; Friend, R.; Gustafson, S.; et al. Watershed Vulnerability and Adaptation Assessments in the Greater Mekong Subregion: Guidelines for Climate Change Practitioners; Greater Mekong Subregion (GMS) Roundtable for Climate Adaptation: Bangkok, Thailand, 2018.

3. Peterson, D.L.; Millar, C.I.; Joyce, L.A.; Furniss, M.; Halofsky, J.E.; Neilson, R.; Morelli, T.L. Responding to Climate Change in National Forests: A Guidebook for Developing Adaptation Options; USDA Forest Service, Pacific Northwest Research Station: Portland, OR, USA, 2011.

4. Füssel, H.-M.; Klein, R.J. Climate change vulnerability assessments: An evolution of conceptual thinking. Clim. Chang. 2006, 75, 301-329. [CrossRef]

5. David-Chavez, D.M.; Gavin, M.C. A global assessment of Indigenous community engagement in climate research. Environ. Res. Lett. 2018, 13, 123005. [CrossRef]

6. Amiott, J. Investigating the Convention on Biological Diversity's protections for traditional knowledge. Mo. Environ. Law Policy Rev. 2003, 11,3-37.

7. Connelly, A.; Carter, J.; Handley, J.F.; Hincks, S. Enhancing the practical utility of risk assessments in climate change adaptation. Sustainability 2018, 10, 1399. [CrossRef]

8. Hares, M. Forest conflict in Thailand: Northern minorities in focus. Environ. Manag. 2008, 43, $381-395$. [CrossRef] [PubMed]

9. Shott, J. Vulnerability and Capacity Assessment (VCA): An Integrated Approach for Local Stakeholders. Powerpoint; Asia Pacific Adaption Network. Available online: http://www.asiapacificadapt.net/ adaptationforum2012/sites/default/files/SDF\%20VCA\%20Synthensized\%20Ver06\%20Adapt\%20Forum.pdf (accessed on 3 February 2020).

10. Dillard, D.; Rose, C.; Conard, S.; MacCleery, D.; Ford, L.; Conant, K.; Cundiff, A.; Trapani, J. Forest Service Strategic Framework for Responding to Climate Change; USDA Forest Service: Washington, DC, USA, 2008.

11. Tkacz, B.; Brown, H.; Daniels, A.; Acheson, A.; Cleland, D.; Fay, F.; Johnson, R.; Kujawa, G.; Roper, B.; Stritch, L. National Roadmap for Responding to Climate Change; USDA Forest Service: Washington, DC, USA, 2010.

12. Joyce, L.A.; Blate, G.M.; McNulty, S.G.; Millar, C.I.; Moser, S.; Neilson, R.P.; Peterson, D.L. Managing for multiple resources under climate change: National forests. Environ. Manag. 2009, 44, 1022-1032. [CrossRef]

13. Swanston, C.; Maria, E.J. Forest Adaptation Resources: Climate Change Tools and Approaches for Land Managers; Gen. Tech. Rep. NRS-GTR-87; USDA Forest Service, Northern Research Station: Newtown Square, PA, USA, 2012.

14. Furniss, M.; Roby, K.B.; Cenderelli, D.; Chatel, J.; Clifton, C.F.; Clingenpeel, A.; Hays, P.E.; Higgins, D.; Hodges, K.; Howe, C.; et al. Assessing the Vulnerability of Watersheds to Climate Change: Results of National forest Watershed Vulnerability Pilot Assessments; Gen. Tech. Rep. PNW-GTR-884; USDA Forest Service, Pacific Northwest Research Station: Portland, OR, USA, 2013. 
15. Spies, T.A.; Giesen, T.W.; Swanson, F.J.; Franklin, J.F.; Lach, D.; Johnson, K.N. Climate change adaptation strategies for federal forests of the Pacific Northwest, USA: Ecological, policy, and socio-economic perspectives. Landsc. Ecol. 2010, 25, 1185-1199. [CrossRef]

16. MacClune, K.; Opitz-Stapleton, S. Building Urban Resilience to Climate Change; ISET-International: Boulder, CO, USA, 2012.

17. Fischer, A.P.; Paveglio, T.; Brenkert-Smith, H.; Carroll, M.; Murphy, D. Assessing social vulnerability to climate change in human communities near public forests and grasslands: A framework for resource managers and planners. J. For. 2013, 111, 357-365. [CrossRef]

18. Swanston, C.W.; Janowiak, M.K.; Brandt, L.A.; Butler, P.R.; Handler, S.D.; Shannon, P.D.; Lewis, A.D.; Hall, K.R.; Fahey, R.T.; Scott, L.; et al. Forest Adaptation Resources: Climate Change Tools and Approaches for Land Managers; Gen. Tech. Rep. NRS-GTR-87-2; USDA Forest Service, Northern Research Station: Newtown Square, PA, USA, 2016.

19. Hand, M.S.; Eichman, H.; Triepke, F.J.; Jaworski, D. Socioeconomic Vulnerability to Ecological Changes to National Forests and Grasslands in the Southwest; Gen. Tech. Rep. RMRS-GTR-383; USDA Forest Service, Rocky Mountain Research Station: Fort Collins, CO, USA, 2018.

20. Armatas, C.A.; Borrie, W.T.; Watson, A.E. Protocol for Social Vulnerability Assessment to Support National Forest Planning and Management: A Technical Manual for Engaging the Public to Understand Ecosystem Service Tradeoffs and Drivers of Change; Gen. Tech. Rep. RMRS-GTR-396; USDA Forest Service, Rocky Mountain Research Station: Fort Collins, CO, USA, 2019.

21. Norton-Smith, K.; Lynn, K.; Chief, K.; Cozzetto, K.; Donatuto, J.; Redsteer, M.H.; Kruger, L.E.; Maldonado, J.; Viles, C.; Whyte, K.P. Climate Change and Indigenous Peoples: A Synthesis of Current Impacts and Experiences; Gen. Tech. Rep. PNW-GTR-944; USDA Forest Service, Pacific Northwest Research Station: Portland, OR, USA, 2016.

22. Norgaard, K.M. Salmon E Acorns Feed Our People: Colonialism, Nature, E Social Action; Rutgers University Press: New Brunswick, NJ, USA, 2019.

23. Tribal Adaptation Menu Team. Dibaginjigaadeg Anishinaabe Ezhitwaad: A Tribal Climate Adaptation Menu; Great Lakes Indian Fish and Wildlife Commission: Odanah, WI, USA, 2019.

24. Case-Scott, H.; Lynn, K. Review of tribal climate change plans. In Understanding Effects of Climate Change on Forest Resources for Tribal Communities in the Pacific Northwest and Northern California; Lake, F.K., Long, J.W., Norgaard, K.M., Lynn, K., Case-Scott, H., Eds.; (unpublished, manuscript in preparation).

25. Reinecke, S.; Blum, M. Discourses across scales on forest landscape restoration. Sustainability 2018, 10, 613. [CrossRef]

26. Biswas, S.; Mallik, A.U.; Choudhury, J.K.; Nishat, A. A unified framework for the restoration of Southeast Asian mangroves-Bridging ecology, society and economics. Wetl. Ecol. Manag. 2008, 17, 365-383. [CrossRef]

27. Keane, R.; Hessburg, P.F.; Landres, P.B.; Swanson, F.J. The use of historical range and variability (HRV) in landscape management. For. Ecol. Manag. 2009, 258, 1025-1037. [CrossRef]

28. Timberlake, T.J. Climate Change Adaptation on Public Lands: Policy, Vulnerability Assessments, and Resilience in the US Forest Service. Ph.D. Thesis, Colorado State University, Fort Collins, CO, USA, 2019.

29. MacQuarrie, P.R. Resilience of Large River Basins: Applying Social-Ecological Systems Theory, Conflict Management, and Collaboration on the Mekong and Columbia Basins. Ph.D. Thesis, Oregon State University, Corvallis, OR, USA, 2012.

30. Smith, T. Climate Vulnerability in Asia's High Mountains; Technical Report to USAID; World Wildlife Fund: Washington, DC, USA, 2014.

31. Foti, R.; Ramirez, J.A.; Brown, T.C. Vulnerability of US Water Supply to Shortage: A Technical Document Supporting the Forest Service 2010 RPA Assessment; USDA Forest Service, Rocky Mountain Research Station: Fort Collins, CO, USA, 2012.

32. Boonyawat, S.; Kheereemangkla, Y.; Puk-ngam, S.; Thueksathit, S.; Tongdeenok, T.; Kaewjampa, N.; Havanond, S.; Sittiyanpaiboon, A. Integrated Watershed Ecosystem Management: A Case of Forest and Water Resources in Bangtranoi and Huaisai Watershed, Cha-am District, Phetchaburi Province; International Conference on Climate Change: Phetchaburi Province, Thailand, 2016.

33. Campbell, J.D.; Taylor, M.A.; Stephenson, T.S.; Watson, R.A.; Whyte, F.S. Future climate of the Caribbean from a regional climate model. Int. J. Clim. 2010, 31, 1866-1878. [CrossRef] 
34. Cayan, D.R.; Maurer, E.; Dettinger, M.D.; Tyree, M.; Hayhoe, K. Climate change scenarios for the California region. Clim. Chang. 2008, 87, 21-42. [CrossRef]

35. Opitz-Stapleton, S.; MacClune, K. Chapter 11 Scientific and social uncertainties in climate change: The Hindu Kush-Himalaya in regional perspective. In Climate Change Modeling for Local Adaptation in the Hindu Kush-Himalayan Region; Lamadrid, A., Kelman, I., Eds.; Emerald Group Publishing Limited: Bingley, UK, 2012.

36. Shrestha, S. Assessment of water availability under climate change scenarios in Thailand. In Climate Change Impacts and Adaptation in Water Resources and Water Use Sectors; Shrestha, S., Ed.; Springer International Publishing: New York, NY, USA, 2014.

37. Steel, E.A.; Marsha, A.; Fullerton, A.H.; Olden, J.D.; Larkin, N.K.; Lee, S.-Y.; Ferguson, A. Thermal landscapes in a changing climate: Biological implications of water temperature patterns in an extreme year. Can. J. Fish. Aquat. Sci. 2019, 76, 1740-1756. [CrossRef]

38. Hall, M. Earth Repair: A Transatlantic History of Environmental Restoration; University of Virginia Press: Charlottesville, VA, USA, 2005.

39. Lasco, R.D.; Cruz, R.; Pulhin, J.; Pulhin, F. Assessing Climate Change Impacts, Vulnerability and Adaptation: The Case of Pantabangan-Carranglan Watershed; World Agroforestry Centre-Philippines: Laguna, Philippines, 2010.

40. Halofsky, J.E.; Peterson, D.L.; O'Halloran, K.A.; Hoffman, C.H. Adapting to Climate Change at Olympic National Forest and Olympic National Park; Gen. Tech. Rep. PNW-GTR-844; USDA Forest Service, Pacific Northwest Research Station: Portland, OR, USA, 2011.

41. Long, J.W.; Lake, F.K. Escaping social-ecological traps through tribal stewardship on national forest lands in the Pacific Northwest, United States of America. Ecol. Soc. 2018, 23, 1-14. [CrossRef]

42. Yusuf, A.A.; Francisco, H. Climate change vulnerability mapping for Southeast Asia. In Economy and Environment Program for Southeast; Economy and Environment Program for Southeast Asia (EEPSEA): Singapore, 2009.

43. Kondolf, G.M. The Espace de Liberté and restoration of fluvial process: When can the river restore itself and when must we intervene. In River Conservation and Management; John Wiley \& Sons, Ltd.: Chichester, UK, 2012; pp. 223-241.

44. Chornesky, E.A.; Ackerly, D.D.; Beier, P.; Davis, F.W.; Flint, L.E.; Lawler, J.J.; Moyle, P.B.; Moritz, M.A.; Scoonover, M.; Byrd, K. Adapting California's ecosystems to a changing climate. Bioscience 2015, 65, 247-262. [CrossRef]

45. Hogan, Z.; Na-Nakorn, U.; Kong, H. Threatened fishes of the world: Pangasius sanitwongsei Smith 1931 (Siluriformes: Pangasiidae). Environ. Biol. Fishes 2008, 84, 305-306. [CrossRef]

46. Kittikhoun, A.; Staubli, D.M. Water diplomacy and conflict management in the Mekong: From rivalries to cooperation. J. Hydrol. 2018, 567, 654-667. [CrossRef]

47. Flood, J.P.; McAvoy, L.H. Use of national forests by Salish? Kootenai tribal members: Traditional recreation and a legacy of cultural values. Leisure/Loisir 2007, 31, 191-216. [CrossRef]

48. Keller, R.H.; Turek, M.F. American Indians and National Parks; University of Arizona Press: Tucson, AZ, USA, 1999.

49. Catton, T. American Indians and National Forests; University of Arizona Press: Tucson, AZ, USA, 2016.

50. McElwee, P.D. Displacement and relocation redux: Stories from Southeast Asia. Conserv. Soc. 2006, 4, 396-403.

51. Jennings, L.N.; Douglas, J.; Treasure, E.; González, G. Climate Change Effects in El Yunque National Forest, Puerto Rico, and the Caribbean Region; Gen. Tech. Rep. SRS-GTR-193; USDA Forest Service, Southern Research Station: Asheville, NC, USA, 2014.

52. Stott, P.A.; Goldammer, J.G.; Werner, W.L. The role of fire in the tropical lowland deciduous forests of Asia. In Ecological Studies; Springer Science and Business Media LLC: Berlin/Heidelberg, Germany, 1990; Volume 84, pp. 32-44.

53. Lake, F.K.; Long, J.W. Fire and Tribal Cultural Resources; Gen. Tech. Rep. PSW-GTR-247; USDA Forest Service, Pacific Southwest Research Station: Albany, CA, USA, 2014.

54. Lynn, K.; Daigle, J.; Hoffman, J.; Lake, F.; Michelle, N.; Ranco, D.; Viles, C.; Voggesser, G.; Williams, P. The impacts of climate change on tribal traditional foods. Clim. Chang. 2013, 120, 545-556. [CrossRef]

55. Kershner, J.; Samhouri, J.F.; James, C.A.; Levin, P.S. Selecting indicator portfolios for marine species and food webs: A Puget Sound case study. PLoS ONE 2011, 6, e25248. [CrossRef] [PubMed] 
56. Spies, T.A.; White, E.M.; Kline, J.D.; Fischer, A.P.; Ager, A.A.; Bailey, J.D.; Bolte, J.; Koch, J.; Platt, E.; Olsen, C.S.; et al. Examining fire-prone forest landscapes as coupled human and natural systems. Ecol. Soc. 2014, 19, 9. [CrossRef]

57. Timberlake, T.J.; Schultz, C.A. Policy, practice, and partnerships for climate change adaptation on US national forests. Clim. Chang. 2017, 144, 257-269. [CrossRef]

58. Timberlake, T.J.; Schultz, C.A. Climate change vulnerability assessment for forest management: The case of the U.S. forest service. Forests 2019, 10, 1030. [CrossRef]

59. James, C.A.; Kershner, J.; Samhouri, J.; O’Neill, S.; Levin, P.S.; Kershner, J. A methodology for evaluating and ranking water quantity indicators in support of ecosystem-based management. Environ. Manag. 2012, 49, 703-719. [CrossRef]

60. Green, D.; Niall, S.; Morrison, J. Bridging the gap between theory and practice in climate change vulnerability assessments for remote Indigenous communities in northern Australia. Local Environ. 2012, 17, $295-315$. [CrossRef]

61. Eriksen, S.E.H.; Aldunce, P.; Bahinipati, C.S.; Martins, R.; Molefe, J.I.; Nhemachena, C.; O’Brien, K.; Olorunfemi, F.; Park, J.; Sygna, L.; et al. When not every response to climate change is a good one: Identifying principles for sustainable adaptation. Clim. Dev. 2011, 3, 7-20. [CrossRef]

62. Gustafson, S.; Cadena, A.J.; Ngo, C.C.; Kawash, A.; Saenghkaew, I.; Hartman, P. Merging science into community adaptation planning processes: A cross-site comparison of four distinct areas of the Lower Mekong Basin. Clim. Chang. 2017, 149, 91-106. [CrossRef]

63. Smajgl, A.; Ward, J. Evaluating participatory research: Framework, methods and implementation results. J. Environ. Manag. 2015, 157, 311-319. [CrossRef]

64. Whyte, K. Indigenous climate change studies: Indigenizing futures, decolonizing the anthropocene. Engl. Lang. Notes 2017, 55, 153-162. [CrossRef]

65. Fillmore, H.M. TahoeLand Live! National Public Radio TahoeLand Podcast. Romero, E.D., Ed.; Available online: http://www.capradio.org/news/tahoeland/2019/10/10/tahoeland-live/ (accessed on 18 October 2019).

66. Berry, P.; Enright, P.M.; Shumake-Guillemot, J.; Prats, E.V.; Campbell-Lendrum, D. Assessing health vulnerabilities and adaptation to climate change: A review of international progress. Int. J. Environ. Res. Public Health 2018, 15, 2626. [CrossRef] [PubMed]

67. Avelino, J.E.; Crichton, R.; Valenzuela, V.P.B.; Odara, M.G.N.; Padilla, M.A.T.; Kiet, N.; Danh, T.N.; Van, P.C.; Bao, H.D.; Linh, M.T.Y.; et al. Survey tool for rapid assessment of socio-economic vulnerability of fishing communities in Vietnam to climate change. Geosciences 2018, 8, 452. [CrossRef]

68. Amuzu, J.; Jallow, B.P.; Kabo-Bah, A.T.; Yaffa, S. The climate change vulnerability and risk management matrix for the coastal zone of the Gambia. Hydrology 2018, 5, 14. [CrossRef]

69. Younus, A.F. An assessment of vulnerability and adaptation to cyclones through impact assessment guidelines: A bottom-up case study from Bangladesh coast. Nat. Hazards 2017, 89, 1437-1459. [CrossRef]

70. O’Brien, K.; Eriksen, S.; Nygaard, L.P.; Schjolden, A.N.E. Why different interpretations of vulnerability matter in climate change discourses. Clim. Policy 2007, 7, 73-88. [CrossRef]

71. Williams, S.E.; Shoo, L.P.; Isaac, J.L.; Hoffmann, A.A.; Langham, G. Towards an integrated framework for assessing the vulnerability of species to climate change. PLoS Biol. 2008, 6, 2621-2626. [CrossRef]

72. Aziz, T.; Van Cappellen, P. Comparative valuation of potential and realized ecosystem services in Southern Ontario, Canada. Environ. Sci. Policy 2019, 100, 105-112. [CrossRef]

73. Taylor, A.H.; Trouet, V.; Skinner, C.N.; Stephens, S. Socioecological transitions trigger fire regime shifts and modulate fire-climate interactions in the Sierra Nevada, USA, 1600-2015 CE. Proc. Natl. Acad. Sci. USA 2016, 113, 13684-13689. [CrossRef]

74. Walsh, M.K.; Duke, H.J.; Haydon, K.C. Toward a better understanding of climate and human impacts on late Holocene fire regimes in the Pacific Northwest, USA. Prog. Phys. Geogr. 2018, 42, 478-512. [CrossRef]

75. Gomes, T.C. Novel ecosystems in the restoration of cultural landscapes of Tl'chés, West Chatham Island, British Columbia, Canada. Ecol. Process. 2013, 2, 15. [CrossRef]

76. Augustine, S.; Dearden, P. Changing paradigms in marine and coastal conservation: A case study of clam gardens in the Southern Gulf Islands, Canada. Can. Geogr. Géogr. Can. 2014, 58, 305-314. [CrossRef]

77. Guerrero-Gatica, M.; Aliste, E.; Simonetti, J.A. Shifting gears for the use of the shifting baseline syndrome in ecological restoration. Sustainability 2019, 11, 1458. [CrossRef]

78. Egan, D. Ecological restoration and sustainable development. Ecol. Restor. 2003, 21, 161-162. [CrossRef] 
79. Tomblin, D.C. The ecological restoration movement. Organ. Environ. 2009, 22, 185-207. [CrossRef]

80. Nagy, G.J.; Filho, W.L.; Azeiteiro, U.M.; Heimfarth, J.; Verocai, J.E.; Li, C. An assessment of the relationships between extreme weather events, vulnerability, and the impacts on human wellbeing in Latin America. Int. J. Environ. Res. Public Health 2018, 15, 1802. [CrossRef]

81. Kelly, P.M.; Adger, W.N. Theory and practice in assessing vulnerability to climate change and facilitating adaptation. Clim. Chang. 2000, 47, 325-352. [CrossRef]

82. Whitney, C.; Bennett, N.J.; Ban, N.C.; Allison, E.; Armitage, D.; Blythe, J.; Burt, J.; Cheung, W.W.L.; Finkbeiner, E.M.; Kaplan-Hallam, M.; et al. Adaptive capacity: From assessment to action in coastal social-ecological systems. Ecol. Soc. 2017, 22. [CrossRef]

83. Creed, I.F.; Van Noordwijk, M. Forest and Water on a Changing Planet: Vulnerability, Adaptation and Governance Opportunities; A Global Assessment Report; International Union of Forest Research Organizations: Vienna, Austria, 2018.

84. Marks-Block, T.; Lake, F.K.; Curran, L.M. Effects of understory fire management treatments on California Hazelnut, an ecocultural resource of the Karuk and Yurok Indians in the Pacific Northwest. For. Ecol. Manag. 2019, 450, 117517. [CrossRef]

85. Long, J.W.; Gray, A.N.; Lake, F.K. Recent trends in large hardwoods in the Pacific Northwest, USA. Forests 2018, 9, 651. [CrossRef]

86. Lemos, M.C.; Kirchhoff, C.J.; Ramprasad, V. Narrowing the climate information usability gap. Nat. Clim. Chang. 2012, 2, 789-794. [CrossRef]

87. Hildén, M.; Jordan, A.; Huitema, D. Special issue on experimentation for climate change solutions editorial: The search for climate change and sustainability solutions-The promise and the pitfalls of experimentation. J. Clean. Prod. 2017, 169, 1-7. [CrossRef]

88. Oakes, L.E.; Hennon, P.E.; Ardoin, N.M.; D’Amore, D.V.; Ferguson, A.J.; Steel, E.A.; Wittwer, D.T.; Lambin, E.F. Conservation in a social-ecological system experiencing climate-induced tree mortality. Biol. Conserv. 2015, 192, 276-285. [CrossRef]

89. Kmoch, L.; Pagella, T.; Palm, M.; Sinclair, F. Using local agroecological knowledge in climate change adaptation: A study of tree-based options in Northern Morocco. Sustainability 2018, 10, 3719. [CrossRef]

(C) 2020 by the authors. Licensee MDPI, Basel, Switzerland. This article is an open access article distributed under the terms and conditions of the Creative Commons Attribution (CC BY) license (http://creativecommons.org/licenses/by/4.0/). 